\title{
HUBUNGAN AKTIVITAS FISIK TERHADAP KUALITAS TIDUR DAN FUNGSI KOGNITIF PADA KELOMPOK LANSIA DHARMA SENTANA, BATUBULAN
}

\author{
I Made Dhita Prianthara ${ }^{1^{*}}$, I.A Pascha Paramurthi², I Putu Astrawan ${ }^{3}$ \\ 1,2,3 Program Studi Fisioterapi, Fakultas Ilmu-Ilmu Kesehatan, \\ Universitas Bali Internasional \\ *e-mail: dhitaprianthara@gmail.com
}

\begin{abstract}
Keywords:

Peningkatan jumlah populasi lansia menyebabkan semakin banyak masalah Lansia, Aktivitas

Fisik, Kualitas kesehatan yang akan dialami oleh lansia yang disebabkan karena Tidur, Fungsi Kognitif kurangnya aktivitas fisik seperti gangguan kualitas tidur dan penurunan fungsi kognitif. Seiring dengan pertambahan usia dan berkurangnya aktivitas fisik, semakin besar kemungkinan seseorang mengalami gangguan kualitas tidur dan penurunan fungsi kognitif. Aktivitas fisik yang rutin dilakukan oleh lansia dapat mencegah terjadinya gangguan kualitas tidur dan mencegah penurunan fungsi kognitif. Semakin meningkat aktivitas fisik maka semakin meningkat kualitas tidur dan fungsi kognitif pada lansia. Tujuan dari penelitian ini adalah untuk mengetahui hubungan antara aktivitas fisik terhadap kualitas tidur dan fungsi kognitif pada kelompok lansia Dharma Sentana, Batubulan. Penelitian ini adalah cross sectional study dengan teknik pengambilan sampel purposive sampling. Penelitian dilakukan di kelompok lansia Dharma Sentana, Batubulan. Sampel penelitian ini berjumlah 50 orang lansia. Aktivitas fisik diukur dengan International Physical Activity Scale (IPAQ), kualitas tidur diukur dengan Pittsburgh Sleep Quality Index (PSQI), dan fungsi kognitif diukur dengan Mini-Mental State Examination (MMSE). Berdasarkan hasil uji chi-square didapatkan nilai $\mathrm{p}=0,007$ yang artinya ada hubungan antara aktivitas fisik dengan kualitas tidur dan nilai $\mathrm{p}=0,000$ yang artinya ada hubungan antara aktivitas fisik dengan fungsi kognitif. Simpulan penelitian ini adalah ada hubungan antara aktivitas fisik terhadap kualitas tidur dan fungsi kognitif pada kelompok lansia Dharma Sentana, Batubulan.
\end{abstract}

\section{PENDAHULUAN}

Lansia merupakan individu yang berada di akhir tahap kehidupan manusia, yang mana proses kemunduran lebih dominan terjadi dibanding dengan

\footnotetext{
* Corresponding Author. Tel: 081999333938
}

kemajuan (Soetjiningsih, 2018).

Peningkatan jumlah lansia di Indonesia dari tahun ke tahun terus mengalami peningkatan seiring dengan meningkatnya Usia Harapan Hidup. Badan Pusat Statistik Indonesia mencatat bahwa pada tahun 2000, Usia Harapan Hidup di Indonesia 
adalah 64,5 tahun dengan persentase populasi lansia adalah $7,18 \%$. Sedangkan pada tahun 2011 Usia Harapan Hidup di Indonesia menjadi 69,65 tahun dengan persentase populasi lansia sebesar 7,58\%. Hasil Survey Sosial Ekonomi Nasional (Susenas) pada tahun 2012 mendapatkan bahwa jumlah penduduk lansia yang ada di Bali adalah 7,78\% dari total keseluruhan lansia di Indonesia (Badan Pusat Statistik, 2018).

Peningkatan jumlah populasi lansia akan menyebabkan semakin banyak masalah kesehatan yang akan dialami oleh lansia yang disebabkan karena proses penuaan. Menghilangnya kemampuan jaringan dalam memperbaiki kerusakan dan mempertahankan fungsi normalnya merupakan salah satu tanda dari adanya proses penuaan (Maryam \& Rosidawati, 2008). Masalah yang sering muncul pada lansia adalah gangguan tidur. Gangguan tidur dapat menyebabkan terjadinya kecelakaan pada saat melakukan aktivitas sehari-hari, peningkatan risiko obesitas, diabetes, tekanan darah tinggi serangan jantung dan stroke pada lansia (CDC, 2018).

Gangguan tidur yang terjadi pada orang dewasa di Indonesia setiap tahun diperkirakan sekitar 35\%-45\%. Prevalensi gangguan tidur pada laki-laki sekitar 35,5\% dan pada perempuan sekitar $34,8 \%$. Sebanyak 86,2\% lansia di Iran yang berusia 60 tahun keatas mengalami gangguan tidur dan membutuhkan waktu sekitar 20 menit untuk memulai tidur (Malakouti et al., 2009). Perubahan pola tidur pada lansia disebabkan oleh adanya perubahan sistem neurologis yang secara fisiologis akan mengalami penurunan jumlah dan ukuran neuron pada sistem saraf pusat. Hal ini mengakibatkan fungsi dari neurotransmitter pada sistem neuron menurun, sehingga distribusi norepinefrin yang merupakan zat untuk merangsang tidur juga akan menurun.

Gangguan tidur pada lansia dapat mempengaruhi kualitas tidur. Kualitas tidur merupakan keadaan dimana seseorang tidak sadar akibat menurun atau hilangnya perseptual individu terhadap faktor lingkungan yang dapat memberikan kebugaran, kesegaran dan kepuasan ketika terbangun (Fakihan, 2016). Terdapat beberapa faktor yang dapat mempengaruhi kualitas tidur yaitu usia, motivasi, aktivitas fisik, diet, kebudayaan, konsumsi alkohol, merokok, gaya hidup, dan penyakit. menjaga kualitas tidur lansia merupakan salah satu hal yang penting untuk dilakukan karena dapat memulihkan fungsi tubuh sehingga dapat melakukan aktivitas fungsionalnya (Triyadini et al., 2010).

Kualitas tidur dapat ditingkatkan dengan cara menjaga aktivitas fisik. Aktivitas fisik merupakan setiap gerakan tubuh yang dihasilkan otot skeletal yang memerlukan pengeluaran energi (Stathokostas, 2012). Aktivitas fisik yang dilakukan oleh lansia dapat meningkatkan konsumsi energi pada tubuh, sekresi endorphin dan peningkatan suhu tubuh sehingga dapat meningkatkan kebutuhan tidur dan peningkatan proses penyembuhan. Disamping itu, aktivitas fisik yang dilakukan secara rutin dapat memberikan dampak yang positif seperti membuat metabolism menjadi lebih baik, merangsang aktivitas saraf simpatis dan saraf parasimpatis sehingga hormone adrenalin, norepinefrin dan ketokolamin menjadi menurun (Bouchard et al., 2012). Aktivitas saraf parasimpatis juga dapat menyebabkan terjadinya vasodilatasi pembuluh darah sehingga peredaran darah menjadi lebih lancar dan menyebabkan efek 
peningkatan relaksasi pada tubuh (Chennaoui et al., 2014).

Aktivitas fisik yang berlebihan pada lansia dapat mempengaruhi kualitas tidur. Akibat aktivitas tersebut, lansia akan memerlukan lebih banyak tidur untuk menjaga keseimbangan energi yang telah dikeluarkan. Lansia yang beraktivitas sampai mencapai tingkat kelelahan maka lansia tersebut akan lebih cepat untuk dapat tidur karena tahap tidur gelombang lambatnya (Non Rapid Eye Movement) diperpendek (Hidayat, 2009). Pola tersebut tidak bagus untuk lansia yang melakukan aktivitas fisik secara berlebihan karena mengakibatkan ketidaknyamanan pada pola hidup lansia dan dapat mengganggu kualitas tidur. Di masa pandemi seperti sekarang ini, aktivitas fisik yang dapat dilakukan juga terbatas. Lansia hanya bisa melakukan aktivitas di rumah sehingga hal tersebut dapat mempengaruhi kualitas tidur dari lansia.

Fungsi kognitif didefinisikan sebagai suatu proses dimana semua masukan sensoris (taktil, visual dan auditorik) akan diubah, diolah, disimpan dan selanjutnya digunakan untuk hubungan interneuron secara sempurna sehingga individu mampu melakukan penalaran terhadap masukan sensoris tersebut (Riani \& Halim, 2019). Fungsi kognitif merupakan bagian terbesar dalam otak dimana adanya penurunan kemampuan kognitif seperti mengalami lupa, kemunduran orientasi terhadap waktu, ruang, tempat, serta tidak mudah menerima hal atau ide baru (Maryam \& Rosidawati 2008). Penurunan fungsi kognitif tentunya mempengaruhi individu dan kehidupan sekitarnya terutama keluarga. Selain itu juga dapat menurunkan kepercayaan diri, kualitas hidup dan fungsinya dalam kehidupan sehari - hari secara mandiri (Chairina et al,. 2020)

Berdasarkan penelitian yang dilakukan Rosdianti et al (2018) menyatakan bahwa sebanyak $75,5 \%$ dari 49 responden dengan aktivitas fisik sehari-hari yang dilakukan secara mandiri memiliki kualitas tidur yang baik dimana lansia yang beraktivitas fisik akan memiliki kondisi tubuh yang bugar dan dapat meningkatkan kualitas tidur. Namun berbeda dengan penelitian yang dilakukan oleh Sofiah (2020) yang menyatakan bahwa tidak ada hubungan kativitas fisik dengan kualitas tidur. Terdapat beberapa faktor yang dapat mempengaruhi kualitas tidur, sehingga faktor aktivitas fisik tidak dapat menjadi faktor tunggal untu penyebab permasalahan dalam kualitas tidur. Menurut penelitian Izzah (2014) menyatakan bahwa terdapat hubungan yang signifikan dari aktivitas fisik dengan fungsi kognitif.

\section{METODE PENELITIAN}

Penelitian ini merupakan penelitian observasional dengan menggunakan rancangan cross sectional study yang dilaksanakan pada bulan Juni-Agustus 2021. Populasi target dalam penelitian ini adalah seluruh lansia yang berada di Kelompok Lansia Dharma Sentana, Batubulan. Populasi terjangkau pada penelitian ini adalah lansia di Kelompok Lansia Dharma Sentana, Batubulan yang memenuhi kriteria inklusi dan ekslusi.

Sampel adalah yang memenuhi kriteria inklusi dan eksklusi. Kriteria Inklusi: a) Bersedia secara sukarela sebagai subjek penelitian dari awal penelitian sampai akhir penlitian dengan menandatangani informed consent bersedia sebagai sampel dalam penelitian. b) Lansia laki-laki maupun perempuan yang berusia 60-75 tahun. c) Lansia dalam kondisi sehat 
yang ditunjukkan dengan vital sign. d) Lansia yang mampu memahami atau mengerti yang disampaikan oleh peneliti. e) Tidak memiliki gangguan musculoskeletal dan gangguan neurologis. Kriteria eksklusi: a) Lansia dengan disabilitas. b) Lansia yang jarang berolahraga. c) Lansia dengan riwayat penyakit kardiovaskular. d) Lansia dengan riwayat penyakit neuromuskular. e) Lansia yang mengkonsumsi obat golongan relaksan. f) Memiliki riwayat trauma kepala. Penelitian ini menggunakan rumus besar sampel yang digunakan adalah total sampling. Populasi Lansia yang ada pada kelompok lansia Dharma Sentana
Batubulan berjumlah 90 orang. Sampel dalam penelitian ini berjumlah 50 orang yang diambil dengan teknik purposive sampling sesuai dengan kriteria inklusi dan ekslusi. Alat ukur yang digunakan dalam penelitian ini adalah International Physical Activity Scale (IPAQ) untuk mengukur aktivitas fisik, Pittsburgh Sleep Quality Index (PSQI) untuk mengukur kualitas tidur dan Mini-Mental State Examination (MMSE) untuk mengukur fungsi kognitif.

\section{HASIL PENELITIAN}

Karakteristik Subjek

Tabel 1. Karakteristik Subjek

\begin{tabular}{|c|c|c|c|}
\hline \multicolumn{2}{|c|}{ Karakteristik } & \multirow[t]{2}{*}{ Frekuensi (f) } & \multirow[t]{2}{*}{ Persentase (\%) } \\
\hline Kelompc & & & \\
\hline & 60-64 tahun & 30 & 60 \\
\hline & 65-69 tahun & 16 & 32 \\
\hline & 70-74 tahun & 2 & 4 \\
\hline & 75-79 tahun & 1 & 2 \\
\hline & $80-85$ tahun & 1 & 2 \\
\hline \multicolumn{4}{|c|}{ Jenis Kelamin } \\
\hline & Laki-laki & 8 & 16 \\
\hline & Perempuan & 42 & 84 \\
\hline \multicolumn{4}{|c|}{ Aktivitas Fisik } \\
\hline & Rendah & 24 & 48 \\
\hline & Sedang & 26 & 52 \\
\hline & Tinggi & 0 & 0 \\
\hline \multicolumn{4}{|c|}{ Kualitas Tidur } \\
\hline & Baik & 14 & 28 \\
\hline & Ringan & 22 & 44 \\
\hline & Sedang & 14 & 28 \\
\hline & Buruk & 0 & 0 \\
\hline \multicolumn{4}{|c|}{ Fungsi Kognitif } \\
\hline & Normal & 24 & 48 \\
\hline & Probable Gangg. Kognitif & 23 & 46 \\
\hline & Definite Gangguan Kognitif & 4 & 6 \\
\hline Jumlah & & 50 & 100 \\
\hline
\end{tabular}


Berdasarkan tabel 1 di atas menunjukkan bahwa subjek terbanyak pada usia 60-64 tahun yaitu sebanyak 30 subjek $(60,0 \%)$, subjek berjenis kelamin perempuan lebih banyak yaitu berjumlah 42 subjek $(84,0 \%)$ daripada subjek yang berjenis kelamin laki-laki sebanyak 8 subjek $(16,0 \%)$, subjek terbanyak pada kategori aktivitas fisik sedang sebanyak 26 subjek (52,0\%), subjek terbanyak pada kategori kualitias tidur ringan sebanyak 22 subjek (44,0\%), dan subjek terbanyak memiliki fungsi kognitif normal sebanyak 24 subjek $(48,0 \%)$.

Tabel 2. Tabel Silang Aktivitas Fisik dengan Kualitas Tidur

\begin{tabular}{|c|c|c|c|c|c|c|c|c|c|c|c|}
\hline \multirow{3}{*}{ Aktivitas Fisik } & \multicolumn{8}{|c|}{ Kualitas Tidur } & \multirow{2}{*}{\multicolumn{2}{|c|}{ Total }} & \multirow{3}{*}{$\mathrm{p}$} \\
\hline & \multicolumn{2}{|c|}{ Baik } & \multicolumn{2}{|c|}{ Ringan } & \multicolumn{2}{|c|}{ Sedang } & \multicolumn{2}{|c|}{ Buruk } & & & \\
\hline & $f$ & $\%$ & $\mathrm{f}$ & $\%$ & $f$ & $\%$ & $\mathrm{f}$ & $\%$ & $\mathrm{n}$ & $\%$ & \\
\hline Rendah & 2 & 4,0 & 12 & 24,0 & 10 & 20,0 & 0 & 0 & 24 & 48,0 & \\
\hline Sedang & 12 & 24,0 & 10 & 20,0 & 4 & 8,0 & 0 & 0 & 26 & 52,0 & 0,007 \\
\hline Tinggi & 0 & 0 & 0 & 0 & 0 & 0 & 0 & 0 & 0 & 0 & \\
\hline Jumlah & 14 & 28,0 & 22 & 44,0 & 14 & 28,0 & 0 & 0 & 50 & 100 & \\
\hline
\end{tabular}

Dari tabel 2 di atas dapat dilihat subjek yang memiliki kualitas tidur baik dengan aktivitas fisik rendah yaitu sebanyak 2 orang $(4,0 \%)$, subjek yang memiliki kualitas tidur baik dengan aktivitas fisik sedang sebanyak 12 orang $(24,0 \%)$. Pada subjek dengan kategori kualitas tidur ringan dengan aktivitas fisik rendah yaitu sebanyak 12
(24,0\%), subjek dengan kualitas tidur ringan dengan aktivitas fisik sedang sebanyak 10 orang $(20,0 \%)$. Selanjutnya, pada subjek dengan kualitas tidur sedang dengan aktivitas fisik rendah yaitu sebanyak 10 orang $(20,0 \%)$, subjek dengan kualitas tidur sedang dengan aktivitas fisik sedang sebanyak 4 orang $(8,0 \%)$.

Tabel 3. Tabel Silang Aktivitas Fisik Dengan Fungsi Kognitif

\begin{tabular}{|c|c|c|c|c|c|c|c|c|c|}
\hline \multirow{3}{*}{ Aktivitas Fisik } & \multicolumn{6}{|c|}{ Fungsi Kognitif } & \multirow{2}{*}{\multicolumn{2}{|c|}{ Total }} & \multirow{3}{*}{$\mathrm{p}$} \\
\hline & \multicolumn{2}{|c|}{ Normal } & \multicolumn{2}{|c|}{$\begin{array}{c}\text { Probable } \\
\text { Gangguan } \\
\text { Kognitif }\end{array}$} & \multicolumn{2}{|c|}{$\begin{array}{c}\text { Definite } \\
\text { Gangguan } \\
\text { Kognitif }\end{array}$} & & & \\
\hline & $f$ & $\%$ & $f$ & $\%$ & $\mathrm{f}$ & $\%$ & $\mathrm{n}$ & $\%$ & \\
\hline Rendah & 0 & 0 & 21 & 42,0 & 3 & 6,0 & 24 & 48,0 & \\
\hline Sedang & 24 & 48,0 & 2 & 4,0 & 0 & 0 & 26 & 52,0 & 0,000 \\
\hline Tinggi & 0 & 0 & 0 & 0 & 0 & 0 & 0 & 0 & \\
\hline Jumlah & 24 & 48,0 & 23 & 46,0 & 3 & 6,0 & 50 & 100 & \\
\hline
\end{tabular}

Dari tabel 3 di atas dapat dilihat subjek yang memiliki fungsi kognitif norma dengan aktivitas fisik sedang yaitu sebanyak 24 orang (48,0\%), subjek yang memiliki fungsi kognitif probable gangguan kognitif dengan aktivitas fisik rendah sebanyak 21 orang (42,0\%), subjek dengan fungsi kognitif probable gangguan kognitif dengan aktivitas fisik sedang sebanyak 2 orang (4,0\%). Sedangkan subjek dengan fungsi kognitif definite 
gangguan kognitif dengan aktivitas fisik rendah sebanyak 3 orang $(6,0 \%)$

\section{PEMBAHASAN}

\section{Karakteristik Responden}

Pada karakteristik berdasarkan usia menunjukkan bahwa subjek terbanyak pada usia 60-64 tahun yaitu sebanyak 30 orang $(60,0 \%)$, usia 65-69 tahun sebanyak 16 orang (32,0\%), usia 70-74 tahun sebanyak 2 orang $(4,0 \%)$, usia 75-79 tahun sebanyak 1 orang (2,0\%) dan usia 80-85 tahun sebanyak 1 orang (2,0\%). Menurut menurut Firman, 2017 menyatakan aktivitas fisik seseorang meningkat sampai mencapai maksimal pada usia 25-30 tahun, kemudian akan terjadi penurunan kapasitas fungsional dari seluruh tubuh kira-kira sebesar $0,8 \%-1 \%$ per tahun. Dalam penelitian ini didapatkan hasil bahwa lansia yang berumur 60-64 tahun memiliki persentase yang lebih banyak dari pada usia yang lebih tua. Lansia memiliki risiko lebih tinggi menderita penyakit oleh karena perubahan fisiologis yang akan berpengaruh pada organ-organ tubuh. Oleh karena itu usia merupakan suatu faktor yang dapat mempengaruhi aktivitas fisik. Lansia pada Kelompok Lansia Dharma Sentana, Batubulan selalu rutin dalam melakukan aktivitas fisik seperti melakukan senam, gotong royong dan melakukan aktivitas rumah lainnya sehingga kesehatan lansia pada kelompok ini dapat terjaga dengan baik.

Berdasarkan jenis kelamin dimana didapatkan bahwa jenis kelamin perempuan lebih banyak yaitu 42 orang $(84,0 \%)$ sedangkan laki-laki sebanyak 8 orang $(16,0 \%)$. Pada kategori jenis kelamin menunjukkan lansia berjenis kelamin perempuan lebih banyak dari pada laki-laki. Hal tersebut menunjukkan bahwa laki-laki ketika sudah memasuki usia lanjut akan lebih sedikit melakukan aktivitas dibandingkan dengan perempuan. Lansia laki-laki kebanyakan hanya melakukan aktivitas duduk bersantai menonton televisi atau membaca koran, sedangkan lansia wanita akan tetap melakukan aktivitas fisik dalam rumah tangga seperti memasak, menyiapkan makanan untuk keluarga, menyapu ataupun aktivitas lainnya. Selain itu, distribusi jenis kelamin perempuan yang lebih besar juga disebabkan oleh perbedaan usia harapan hidup antara laki-laki dan perempuan dimana angka harapan hidup perempuan lebih tinggi dari laki-laki (Kemenkes RI, 2017).

Pada penelitian ini didapatkan hasil subjek terbanyak pada kategori aktivitas fisik sedang sebanyak 26 subjek $(52,0 \%)$ dan pada aktivitas fisik rendah sebanyak 24 orang $(48,0 \%)$. Semakin bertambah usia maka kemampuan fisik seseorang juga akan menurun. Hal tersebut mengakibatkan timbulnya berbagai macam gangguan yang terjadi pada lansia sehingga mengakibatkan lansia jarang untuk melakukan aktivitas.

Subjek terbanyak pada kategori kualitias tidur ringan sebanyak 22 subjek $(44,0 \%)$, dengan kategori baik sebanyak 14 orang $(28,0 \%)$, dengan kategori sedang sebanyak 14 orang $(28,0 \%)$ dan tidak ada yang mengalami kualitar tidur yang buruk. Banyaknya lansia yang mengalami gangguan kualitas tidur dari ringan hingga sedang disebabkan oleh karena perubahan yang terjadi pada lansia baik secara anatomi atau fisiologis dapat menyebabkan waktu tidur yang kurang efektif dan semakin berkurang. Perubahan tersebut mengakibatkan lansia banyak mengalami berbagai macam gangguan seperti gangguan muskuloskeletal ataupun gangguan lainnya sehingga menyebabkan terganggunya waktu tidur lansia.

Subjek terbanyak memiliki fungsi kognitif normal sebanyak 24 subjek $(48,0 \%)$, sebanyak 23 orang $(46,0 \%)$ mengalami probable gangguan kognitif dan lansia yang mengalami definite gangguan kognitif sebanyak 4 orang $(6,0 \%)$. Hal ini disebabkan oleh karena usia seseorang sesungguhnya mempengaruhi fungsi kognitif seseorang 
karena pada setiap pertambahan usia akan terjadi perubahan pada sistem saraf pusat di bagian intelegensi, memori, serta perkembangan psikologis yang menjelaskan hubungan antara penuaan dan fungsi kognitif (Miller, 2012).

\section{Hubungan Aktivitas Fisik dengan Kualitas Tidur}

Berdasarkan hasil penelitian didapatkan subjek yang memiliki kualitas tidur baik dengan aktivitas fisik rendah yaitu sebanyak 2 orang $(4,0 \%)$, subjek yang memiliki kualitas tidur baik dengan aktivitas fisik sedang sebanyak 12 orang (24,0\%). Pada subjek dengan kategori kualitas tidur ringan dengan aktivitas fisik rendah yaitu sebanyak $12(24,0 \%)$, subjek dengan kualitas tidur ringan dengan aktivitas fisik sedang sebanyak 10 orang $(20,0 \%)$. Selanjutnya, pada subjek dengan kualitas tidur sedang dengan aktivitas fisik rendah yaitu sebanyak 10 orang $(20,0 \%)$, subjek dengan kualitas tidur sedang dengan aktivitas fisik sedang sebanyak 4 orang $(8,0 \%)$. Hasil penelitian setelah dilakukan uji chi-square untuk membuktikan adanya hubungan antara aktivitas fisik dengan kualitas tidur pada lansia diperoleh nilai $p$ sebesar 0,007 $(\mathrm{p}<0,05)$.

Aktivitas fisik yang dilakukan secara teratur dapat meningkatkan kualitas tidur. Lansia yang ada di Kelompok Lansia Dharma Sentana Batubulan ini memiliki aktivitas senam yang rutin dilakukan setiap minggu selain melakukan aktivitas rumah lainnya. Aktivitas fisik yang dilakukan sehari-hari oleh lansia dalam kategori sedang ataupun tinggi membutuhkan kondisi fisik yang baik, semakin baik kondisi fisik yang dimiliki maka semakin mudah dalam melakukan kegiatan ataupun aktivitas fisik. Aktivitas fisik sangat berguna bagi kesehatan lansia, karena aktivitas fisik dapat mendorong jantung tetap bekerja dengan baik. Aktivitas fisik juga dapat memperkuat tulang, mengembalikan kelenturan sistem saraf dan mengurangi kecemasan yang mengganggu tidur. Sehingga dengan berkurangnya kecemasan, kualitas tidur lansia akan membaik (Darmodjo, 2011).

Aktivitas fisik yang dilakukan dengan teratur dapat meningkatkan konsumsi energi, sekresi endorphin dan suhu tubuh yang dapat memfasilitasi tidur dalam proses pemulihan tubuh. Aliran darah yang lancar akan menyebabkan oksigen ke otak menjadi Iancar sehingga hal ini dapat mengontrol tekanan darah yang kemudian dapat meningkatkan rasa nyaman saat tidur (Chennaoui et al., 2014).

Penelitian ini sejalan dengan penelitian yang dilakukan oleh Dewi (2020) menyatakan bahwa terdapat hubungan yang bermakna antara aktivitas fisik dengan kualitas tidur pada usia lanjut di Desa Sumerta Kelod. Aktivitas fisik adaIah salah satu cara yang dapat dilakukan untuk meningkatkan kualitas tidur pada usia lanjut. Aktivitas fisik merupakan semua pergerakan sebagai hasil dari kontraksi otot rangka yang memerlukan energi. Aktivitas fisik menyebabkan peningkatan konsumsi energi, sekresi endorphin dan suhu tubuh yang dapat meningkatkan kebutuhan tidur dan proses penyembuhan tubuh. Melalui aktivitas fisik dapat merangsang aktivitas saraf simpatis dan aktivitas saraf parasimpatis sehingga hormon adrenalin, norepinefrin dan katekolamin menurun (Chennaoui et al., 2014). Sistem saraf simpatis diaktivasi ketika beraktivitas fisik yang menyebabkan peningkatan denyut jantung, sedangkan sistem saraf parasimpatis menyebabkan proses pemulihan. Aktivitas saraf parasimpatis akan menyebabkan terjadinya vasodilatasi pembuluh darah yang menyebabkan oksigen ke otak dan seluruh tubuh menjadi lancar sehingga menyebabkan peningkatan relaksasi (Komsiatiningsih, 2015).

Penelitian ini juga sejalan dengan penelitian yang dilakukan oleh Fitria dan 
Aisyah, 2020 yang menyatakan bahwa ada hubungan antara aktivitas fisik dengan kualitas tidur pada lanjut usia di Desa Babah Dua Kecamatan Tadu Raya Kabupaten Nagan Raya Tahun 2019. Salah satu cara meningkatkan kualitas tidur dengan menjaga aktivitas fisik. Aktivitas fisik akan menyebabkan kelelahan yang kemudian menghasilkan proten delta inducing pepide sleep (DIPS) dan membeuat kualitas tidur menjadi lebih baik (Fitria dan Aisyah, 2020).

Latihan dan kelelahan dapat mempengaruhi kualitas dan kuantitas tidur karena keletihan akibat aktivitas yang tinggi dapat memerlukan lebih banyak tidur untuk menjaga keseimbangan energi yang telah dikeluarkan. Hal tersebut dapat terlihat pada orang yang telah melakukan aktivitas dan mencapai kelelahan maka orang tersebut akan lebih cepat untuk dapat tidur karena tahap tidur gelombang lambatnya atau Non Rapid Eye Movement (NREM) diperpendek (Potter \& Perry, 2010).

\section{Hubungan Aktivitas Fisik dengan Fungsi Kognitif}

Hasil penelitian menunjukkan subjek yang memiliki fungsi kognitif norma dengan aktivitas fisik sedang yaitu sebanyak 24 orang (48,0\%), subjek yang memiliki fungsi kognitif probable gangguan kognitif dengan aktivitas fisik rendah sebanyak 21 orang $(42,0 \%)$, subjek dengan fungsi kognitif probable gangguan kognitif dengan aktivitas fisik sedang sebanyak 2 orang (4,0\%). Sedangkan subjek dengan fungsi kognitif definite gangguan kognitif dengan aktivitas fisik rendah sebanyak 3 orang $(6,0 \%)$. Hasil penelitian setelah dilakukan uji chi-square untuk membuktikan hubungan antara aktivitas fisik dengan fungsi kognitif pada lansia diperoleh nilai $p$ sebesar $0,000(\mathrm{p}<0,000)$.

Data penelitian yang diperoleh responden yang fungsi kognitifnya terganggu yang melakukan aktivitas fisik kurang atau rendah berjumlah 24 responden dan responden yang fungsi kognitifnya tidak terganggu yang melakukan aktivitas fisik baik atau sedang berjumlah 26 responden. Tingkat aktivitas fisik seseorang yang baik mempunyai hubungan dengan tingginya skor fungsi kognitif sedangkan lansia yang mengurangi durasi dan intensitas aktivitas fisik memungkinkan proses penurunan fungsi kognitifnya akan lebih cepat.

Penelitian ini sejalan dengan Noor dan Merijanti, 2020 yang menyatakan bahwa terdapat hubungan yang bermakna antara aktivitas fisik dengan fungsi kognitif pada lansia. Aktivitas fisik dapat mempengaruhi fungsi kognitif pada lansia. Lansia dengan aktivitas fisik golongan regular sampai dengan aktif memiliki nilai fungsi kognitif yang normal dibandingkan dengan lansia tanpa aktivitas fisik.

Mekanisme yang menjelaskan hubungan antara aktivitas fisik dengan fungsi kognitif dimana aktivitas fisik dapat menstimulasi pertumbuhan saraf yang kemungkinan dapat menghambat penurunan fungsi kognitif pada lansia (Muzamil et al,. 2014). Menurut Kirk-Sanchez dan McGough (2013) saat melakukan aktivitas fisik, otak akan distimulasi sehingga dapat meningkatkan protein di otak yang disebut Brain Derived Neutrophic Factor (BDNF). Protein BDNF ini berperan penting menjaga sel saraf tetap bugar dan sehat. Namun, apabila kadar BDNF rendah maka akan menyebabkan penyakit kepikunan. Menjamin perfusi jaringan otak yang kuat, efek langsung terhadap otak yaitu memelihara struktur saraf dan meningkatkan perluasan serabut saraf, sinapsis, dan kapilaris. Aktivitas fisik dapat menstimulasi faktor tropik dan neuronal growth yang kemungkinan faktor ini dapat meghambat penurunan fungsi kognitif. Aktivitas fisik dapat juga meningkatkan vaskularisasi di otak, peningkatan level dopamin, dan perubahan molekuler pada 
farktor neuro yang bermanfaat sebagai fungsi fungsi neuroprotective (Muzamil et al,. 2014).

Aktivitas fisik dapat mempertahankan aliran darah yang optimal dan meningkatkan penghantar nutrisi menuju ke otak. Selain itu aktivitas fisik juga memfasilitasi metabolisme neurotransmiter, menghasilkan faktor tropik yang merangsang proses neurogenesis, meningkatkan stimulasi aktivitas molekuler dan selular di otak yang dimana nantinya mendukung dan menjaga plastisipasi otak. Proses ini penting untuk menghambat hipertrofi jaringan otak yang dapat menyebabkan degenerasi neuroral yang berdampak terhadap kognitif. Berdasarkan hasil penelitian sebelumnya mendapatkan hasil lansia yang melakukan aktivitas fisik dengan aktif memiliki fungsi kognitif yang lebih tinggi dibandingkan dengan lansia yang melakukan aktivitas fisik yang kurang aktif, maka disumpulkan bahwa terdapat hubungan antrara aktivitas fisik dengan fungsi kognitif (Muzamil et al., 2014).

Studi yang dilakukan oleh Guimaraes 2014 menyatakan bahwa aktivitas fisik dapat meningkatkan kerja memori, fungsi eksekutif, perhatian, dan memori jangka pendek/ panjang. Aktivitas fisik adalah setiap gerakan tubuh yang membutuhkan pengeluaran tenaga seperti berkebun, berjalan-jalan, melakukan pekerjaan rumah, bersepeda menari dan juga senam. Aktivitas fisik diduga berkontribusi dalam meningkatkan kinerja kognitif melalui peningkatan kadar neurotropin, kebugaran tubuh, mengurangi depresi, mempertahankan aliran darah otak vaskularisasi serta meningkatkan persediaan nutrisi otak, serta menangani dan mencegah penyakit kronis dengan baik (Pathy et al., 2006).

Aktivitas fisik menurunkan kejadian berbagai faktor penyakit vaskular seperti hipertensi, obesitas, dan diabetes yang berhubungan dengan meningkatnya kejadian gangguan fungsi kognitif.Selain itu, dikatakan bahwa aktivitas fisik memiliki efek positif terhadap fungsi kognitif melalui pengaruhnya terhadap brain-derived neurotropic factor (BDNF) (Middleton et al., 2010).

Lansia pada kelompok ini rutin melakukan aktivitas olahraga seperti senam setiap minggunya. Berdasarkan penelitian Carvalho et al., 2014 menyatakan bahwa olah raga aerobik lebih efektif dalam memperlambat proses degeneratif yang berpengaruh terhadap penurunan fungsi kognitif secara fisiologis. Salah satu hipotesis yang dapat menjelaskan hubungan antara aktivitas fisik dan fungsi kognitif adalah melalui jalur neurotrophin otak. Neurotrophin merupakan suatu protein yang mempengaruhi perkembangan dan fungsi dari saraf. Diantara neurotrophin lain, BDNF merupakan neurotrophin yang paling banyak diekspresikan pada otak sehingga mempengaruhi diferensiasi neuron dan proteksi dari kematian neuron di hippocampus. Aktivitas fisik mempengaruhi produksi dari BDNF pada area penting yang mengatur memori, seperti hippocampus (Phillips et al., 2014).

\section{SIMPULAN DAN SARAN}

Berdasarkan tujuan dan hasil penelitian di atas, maka dapat disimpulkan sebagai berikut :

1. Ada hubungan antara aktivitas fisik terhadap kualitas tidur pada lansia

2. Ada hubungan antara aktivitas fisik terhadap fungsi kognitif pada lanjut usia.

\section{DAFTAR PUSTAKA}

[1] Badan Pusat Statistik (BPS). (2018). Statistik Penduduk Lansia 2017. Jakarta: BPS.

[2] Bouchard C, BIair S, \& Haskell W. (2012). PhysicaI Activity and HeaIth 2nd Edition. United States: Human Kinetics.

[3] Carvalho, A., Rea, I. M., Parimon, T. (2014). Physical activity and cognitive function in individuals over 60 years of 
age : a systematic review. Dove Press, 9, 661-682. doi: 10.2147/CIA.S55520.

[4] CDC. (2018). Getting Enough Sleep. The American Academy of Sleep Medicine and the Sleep Research Society. Centers for Disease Control and Prevention.

[5] Chairina, A.N \& Merijanti, L.T. (2020). Hubungan antara Aktivitas Fisik dengan Fungsi Kognitif pada Lansia. Jurnal Biomedika dan Kesehatan, Vol. 3 No. 1

[6] Chennaoui M, ArnaI P, Savet F, Ieger D. (2014). SIeep and Exercise: A ReciprocaI Issue?. SIeep Medicine Review 20, 1-14.

[7] Darmodjo, R. (2011). Buku Ajar Geriatric (Ilmu Kesehatan Lanjut Usia) Edisi Ke-4. Jakarta: FKUI

[8] Dewi, A.A.I., Wahyuni, N., Andayani, N.L.N., Griadhi, I.P.A. (2020). Hubungan AKtivitas Fisik dengan Kualitas Tidur pada Usia Lanjut di Desa Sumerta Kelod. Majalah Ilmiah Fisioterapi Indonesia Vol. 8, No. 1

[9] Fakihan, A. (2016). Hubungan Aktivitas Fisik dengan Kualitas Tidur pada Lanjut Usia. [Skrips]. Universitas Muhammadiyah Surakarta. Surakarta.

[10] Fatmah. (2010). Gizi Usia Lanjut terhadap aktivitas fisik Jakarta: PT Penerbit Erlangga

[11] Fitira, A \& Aisyah, S. (2020). Hubungan Aktivitas Fisik Dengan Kualitas Tidur Pada Lanjut Usia Di Desa Babah Dua. Gentle Birth Vol. 3, No. 1

[12] Guimarães AV, Saulo V R, Aline R B . (2014). Exercise and cognitive performance in older adults: a systematic review. Medicina 47 (4).

[13] Hidayat A. (2009). Pengantar Kebutuhan Dasar Manusia Aplikasi Konsep dan Proses Keperawatan Edisi 2. Surabaya: SaIemba Medika.

[14] Izzah. A. (2014). Hubungan Aktivitas Fisik dengan Fungsi Kognitif Lansia pada Lansia Usia 60-69 Tahun di Kelurahan Purwantoro Kecamatan Blimbing Kota Malang. Saintika Medika: Jurnal Bidang Kedokteran dan Kesehatan Vol. 10, No. 2.
[15] Kemenkes RI. (2017). AnaIisis Lansia di Indonesia. Jakarta: Kementerian Kesehatan RI.

[16] Komsiatiningsih. (2015). Pengaruh Program Rutin Exercise Aerobik dan Pemberian Iatihan ReIaksasi Otot Progresif Terhadap Latensi dan Durasi Tidur Pada Lansia di UPT PSIU Magetan. FakuItas Keperawatan Universitas Airlangga Surabaya.

[17] Malakouti S, Foroughan M, Nojomi M, Ghalebandi M, Zandi T. (2009). SIeep Patterns, Sleep Disturbances and Sleepiness in Retired Iranian EIders. InternationaI JournaI of Geriatric Psychiatry 24 (11), 1201-1208.

[18] Maryam \& Rosidawati. (2008). Mengenal Usia Lanjut dan Perawatannya. Jakarta: Salemba Medika.

[19] Middleton LE, Barnes DE, Lui LY, et al. (2010). Physical activity over the life course and its association with cognitive performance and impairment in old age. J Am Geriatr Soc. 7:1322-6.

[20] Miller, C.A. (2012). Nursing for Wellness in Older Adults (6th Ed.). Philadelphia: Lippincott Williams \& Wilkins.

[21] Muzamil, M.S., Afriwadi, \& Martini, R.D. (2014). Hubungan antara aktivitas fisik dengan fungsi kognitif pada usila di kelurahan jati kecamatan padang timur. Jurnal Fakultas Kedokteran Universitas Andalas, 3 (2), 202-205.

[22] Noor, C.A. \& Merijanti, L.T. (2020). Hubungan antara Aktivitas Fisik dengan Fungsi Kognitif pada Lansia. Jurnal Biomedika dan Kesehatan Vol. 3 No. 1

[23] Pathy, M J , Sinclair, A J \& Morley, J E. (2006). Principle and Practice of Geriatric Medicine. 4th ed. England: John Wiley \& Sons, Ltd.

[24] Phillips C, Baktir MA, Srivatsan M, et al. (2014). Neuroprotective effects of physical activity on the brain: A closer look at trophic factor signaling. Front Cell Neurosci. 8:1-16.

[25] Potter \& Perry. (2010). Fundamental of Nursing: Consep, Proses and Practice $7^{\text {th }}$ ed. Vol. 3. Jakarta : EGC 
[26] Riani, A.D \& Halim, M.S. (2019). Fungsi Kognitif Lansia yang Beraktivitas Kognitif secara Rutin dan Tidak Rutin. Jurnal Psikologi Vol 46, No. 2

[27] Rosdianti Y, HerIina, Hasanah O. (2018). Hubungan Activity of Daily Living (ADL) dengan Kualitas Tidur pada Lansia di PSTW KhusnuI Khotimah Pekanbaru. JOM FKp 5 (2), 660-666.

[28] Soetjiningsih, C. H. (2018). Seri Psikologi Perkembangan: Perkembangan Anak Sejak Pembuahan Sampai dengan Kanak-Kanak Akhir. Kencana.
[29] Sofiah, S., Rachmawati, K., Setiawan. (2020). Hubungan Aktivitas Fisik Dengan Kualitas Tidur Pada Santriwati Pondok Pesantren Darul Hijrah Puteri. Jurnal Keperawatan dan Kesehatan.

[30] Stathokostas, L. (2012). Flexibility Training and Functional Ability in Older Adults: A Systematic Review. Journal of aging research.

[31] Triyadini, Asrin, Upoyo A. (2010). Efektifitas Terapi Massage Dengan Terapi Mandi Air Hangat Terhadap Penurunan Insomnia Lansia. JurnaI Keperawatan Soedirman 5 (3), 174181. 
